\title{
Kajian Aksiologi terhadap Teknologi Pendeteksi Kelainan Bawaan Pada Bayi Dalam Kandungan
}

\author{
Raden Ahmad Hadian Adhy Permana \\ Mahasiswa Program Doktoral Universitas Pendidikan Indonesia \\ Email: r.ahmadhadian@gmail.com
}

\begin{abstract}
Technological devices are applications of science which developed by scientists. Technology in health or medicine now has advanced and supports health practitioners to provide services for the community. One of the used is for examination of the health of the fetus in the womb. Health or abnormalities in the fetus in the womb can be detected by early screening using technological devices and standardized methods. The application of technology or science has limits on the value beside the perceived benefits. Excesses that may arise from the application of technology is the impact of several factors, especially from users, in this case are parents who are not ready if they get offspring that have a congenital abnormality. Violations of ethics and law, in the form of abortion, can occur due to information provided by the use of such technology. Scientists or competent science practitioners need to anticipate the violation of humanitarian values according to the use technological devices which they responsible.
\end{abstract}

Keyword:Technology, ethics, values

\section{Pendahuluan}

Sains (natural science) berkembang terus menghasilkan berbagai produknya seiring dengan perkembangan proses sains itu sendiri. Produk-produk sains berupa fakta, data, konsep, ataupun teori kemudian diaplikasikan ke dalam berbagai bidang yang terkait.Aplikasi berupa teknologi adalah bidang yang sangat pesat perkembangannya dalam beberapa dekade terakhir.Momentum yang diawali dengan pengembangan teknologi mesin uap oleh James Watt menjadi semakin pesat melewati berbagai momentum lainnya sampai di masa sekarang yang telah memasuki era teknologi digital dan internet.

Perkembanganilmu di bidang kesehatan semakin menjadi perhatian masyarakat saat ini. Satu sisi adalah semakin dikenalnya berbagai jenis penyakit dan kelainan yang dapat menyerang manusia, di sisi lain berupa perkembangan ilmu kedokteran yang diperlukan untuk mengatasi penyakit atau kelainan-kelainan tersebut. IImu kedokteran atau kesehatan manusia adalah ilmu yang didasari kajian-kajian Biologi dan Kimia.Penyebab penyakit ataupun kelainan bawaan dapat dipelajari dengan dasar ilmu Biologi serta Biokimia.Penyembuhan penyakit menggunakan pengobatan atau ilmu farmasi adalah turunan dari ilmu Kimia yang mempelajari berbagai senyawa atau zat yang bermanfaat melawan penyakit.Teknologi kemudian masuk ke dalam ilmu kedokteran untuk membantu para ilmuwan dalam bidang kesehatan mendeteksi ataupun mengobati berbagai penyakit atau kelainan yang terjadi.Teknologi tersebut membantu para dokter untuk melakukan "pekerjaan" yang tidak bisa dilakukan menggunakan indera manusia. IImu kesehatan sangat terbantu dengan teknologi yang telah berkembang sejak lama, misalnya alat berupa mikroskop dan perangkat rontgen, sampai di masa sekarang, misalnya perangkat ultrasonografi 3 dimensi dan berbagai perangkat tes kesehatan digital yang memiliki presisi tinggi.

Filsafat merupakan ilmu yang salah satu obyek formalnya adalah implikasi moral-etis dari aplikasi pengetahuan ilmiah (Firman, 2018). Dalam ilmu filsafat terdapat istilah aksiologi. Aksiologi berasal dari kata Yunani: axion (nilai) dan logos (teori), yang berarti teori tentang nilai (Salam, 1997). Sumantri (1996) menyatakan aksiologi adalah teori nilai yang berkaitan dengan kegunaan dan pengetahuan yang diperoleh. Sedangkan Wihadi meyatakan aksiologi adalah kegunaan ilmu pengetahuan bagi kehidupan manusia, kajian tentang nilai-nilai khusunya etika. Abdulhak (2008), menyatakan aksiologi sebagai nilai kegunaan teoritis dan nilai kegunaan praktis. Barnadib (1996) menyatakan bahwa Ide tradisional telah mengatakan bumi ini tetap dan manusia mengetahui hakiki mengenai bumi dan perkara-perkara nilai murni, sementara nihilisme dan irasionalisme adalah menolak semua dugaan dan ketentuan. Jalaludin (1997) tiada kebenaran mutlak, yang 
berlaku umum, bersifat tetap, yang berdiri sendiri, lepas dari akal yang mengenal. Sebab, pengalaman kita berjalan terus dan segala yang kita anggap benar dalam perkembangan pengalaman itu senantiasa berubah. Hal itu disebabkan karena dalam perkembangannya ia dapat dikoreksi oleh pengalaman berikutnya

Aplikasi ilmu pengetahuan berupa produk teknologi semakin maju di era digital saat ini, dimana penemuan-penemuan para ilmuwan zaman dulu seperti Thomas Alfa Edison atau Galileo Galilei telah berulang-ulang dikembangkan oleh para ilmuwan zaman sekarang untuk memenuhi berbagai kebutuhan manusia.Teknologi dalam bidang kesehatan menjadi kebutuhan saat ini seiring kesadaran orang untuk hidup sehat dan keinginan panjang umur. IImu kedokteran dan teknologi yang berkembang di bidang kesehatan saat ini telah sangat maju dan mungkin tidak pernah terpikirkan oleh ilmuwan dalam bidang kesehatan zaman dulu seperti Alexander Fleming sang penemu anti biotik atau Louis Pasteur yang mengembangkan Pasteurisasi makanan dan vaksinasi. Perkembangan aplikasi ilmu pengetahuan tersebut patut mendapat kajian secara filsafat moral-etis karena tidak terlepas kemungkinan ilmu pengetahuan menjadi bebas nilai dengan alas an kesejahteraan manusia.

Etika yang akan dibahas dalam artikel ini terkait dengan perkembangan teknologi di bidang kesehatan yang memiliki potensi penyimpangan dari tujuan pengembangannya. Ilmu kesehatan dan bidang-bidang yang terkait dikembangkan untuk membuat manusia sehat selama kehidupannya. Manusia sudah hidup sejak masa di dalam kandungan, kemudian lahir dan tumbuh berkembang sampai usia tertentu, kemudian mati karena berbagai penyebab termasuk penyakit atau kelainan pada fisiknya. IImu kesehatan mempelajari bagaimana cara menghindari penyakit, mengetahui penyakit dan sumbernya, serta upaya mengobati penyakit atau kelainan fisik manusia. Perkembangan teknologi menyebabkan ilmu kesehatan mampu diterapkan sedini mungkin pada kehidupan manusia, yaitu sejak dalam kandungan. Orangtua yang akan memiliki anak tentunya akan berharap bayinya yang lahir adalah bayi yang sehat dan tidak memiliki kelainan bawaan. Harapan orang tua itulah yang perlu mendapat perhatian dari segi moral-etis dengan adanya teknologi yang mampu mendeteksi penyakit atau kelainan sejak dalam kandungan.Jangan sampai teknologi yang bertujuan mulia menjadi teknologi yang disalahgunakan untuk mendapatkan keturunan hanya yang sehat dan "normal".

Apakah perkembangan teknologi dalam bidang kesehatan boleh bebas nilai karena bertujuan sepenuhnya untuk kesejahteraan manusia?Apakah peralatan-peralatan kesehatan yang digunakan para dokter bisa digunakan untuk menentukan masa hidup manusia? Apakah teknologi kesehatan etis digunakan untuk menseleksi manusia yang lahir?Bagaimana seharusnya teknologi tersebut tetap bermanfaat secara etis dan sesuai moral? Pertanyaan-pertanyaan filosofis tersebut akan dikaji dalam artikel kajian aksiologi ini.

\section{Metode}

Artikel merupakan hasil dari kajian filsafat yang menerapkan metode studi kepustakaan melalui penelaahan terhadap literatur-literatur yang relevan.Informasi juga diperoleh dari hasil-hasil penelitian empiris yang digunakan sebagai bahan kajian tambahan (sekunder)mengenai teknologi dalam bidang kesehatan yang berkembang saat ini. Kajian filsafat yang dilakukan adalah kajian aksiologis.

\section{Hasil dan Pembahasan}

\section{Teknologi Kedokteran untuk Kesehatan Kehamilan}

Pemeriksaan kehamilan telah lama dilakukan menggunakan perangkat ultrasonografi (USG).Bagi masyarakat awam, fungsi USG sepertinya hanya untuk mengetahui jenis kelamin janin atau ukuran badannya saja, padahal alat tersebut memiliki fungsi yang lebih dari itu.USG adalah alat pemeriksaan dengan menggunakan ultrasound (gelombang suara) yang dipancarkan oleh transduser.Suara merupakan fenomena fisika untuk mentransfer energi dari satu titik ke titik yang lainnya sehingga mendapatkan gambaran yang jelas hampir semua bagian tubuh, kecuali bagian tubuh yang dipenuhi udara atau ditutupi tulang (www.integra.co.id).Alat USG memang tidak hanya digunakan untuk memeriksa janin dalam kandungan, tetapi organ-organ dalam tubuh lainnya.

Perkembangan teknologi membuat USG sebagai alat pemeriksaan kehamilan semakin berkembang. Saat ini dikenal ada 3 jenis perangkat USG, yaitu USG 2 dimensi (2D), 3 dimensi (3D), dan 4 dimensi (4D). USG 2D menghasilkan gambar "datar" yang tidak terlalu jelas karena terlihat hanya dari satu sisi dan biasanya sulit dipahami oleh pasien, dapat digunakan untuk 
melihat organ-organ internal, melihat gerakan bayi, mengukur panjang dan berat janin, serta untuk mendeteksi kelainan. USG 3D menghasilkan gambar tiga dimensi yang lebih detail sehingga mudah dipahami oleh pasien, dapat digunakan untuk melihat anatomi tubuh janin dan mendeteksi kondisi kelainan pada janin. USG 4D paling canggih karena dapat menghasilkan gambar tiga dimensi, lebih detail, akurat, dan tampak seperti aslinya, dapat melihat dengan jelas bentuk anggota tubuh, gerakan janin, dan ekspresi wajahnya, seperti bentuk hidung bayi, gerakan sedang mengisap jempol, atau menggerakan kaki, dapat mendeteksi kelainan pada janin dengan lebih jelas.seperti kelainan plasenta atau kehamilan ektopik.(www.integra.co.id)

USG hanya dapat mendeteksi dengan akurasi tinggi pada sebagian kelainan kromosom, untuk kelainan kromosom seperti Sindrom Down USG hanya dapat menjadi indikasi awal saja atau disebut screening. Kesehatan janin dapat pula diperiksa dengan melakukan metode-metode lain yang lebih mendalam. Metode lain tersebut antara lain: Amniosentesis, Chorionic villus sampling(CVS), dan Fetal blood sampling (www.alodokter.com).Amniosentesis adalah pemeriksaan kelainan kromosom bayi dengan pengambilan sampel cairan ketuban, pemeriksaan memiliki tingkat keakuratan 99 persen dalam mendeteksi hampir semua jenis kelainan kromosom. CVS adalah tes yang dapat menemukan masalah tertentu pada janin, termasuk penyakit pada kelainan genetik dan kelainan kromosom. Fetal blood samplingadalah tes untuk mendeteksi kelainan kromosom atau genetika yang dilakukan dengan mengambil sampel darah bayi langsung dari tali pusar atau janin.Metode-metode tersebut adalah hasil pengembangan ilmu pengetahuan dalam bidang kesehatan serta pemanfaatan teknologi yang relevan.

\section{Kelainan pada Janin}

Penyakit atau kelainan pada manusia tidak hanya terjadi setelah seseorang dilahirkan kemudian tumbuh dan berkembang.Penyakit atau kelainan dapat terjadi pada awal kehidupan atau pada masa dalam kandungan. Kelainan bawaan atau paparan bibit penyakit yang masuk ke tubuh janin dapat terjadi sebagai suatu proses yang alami. Kondisi kelainan fisik pada janin antara lainberupa bibir sumbing, bayi terlilit tali pusar, danspina bifida(www.alodokter.com).Kelainan yang dapat terjadi pada manusia dan banyak dibahas terkait pemeriksaan dini pada kandungan menggunakan USG dan metode lanjutannya adalah Sindrom Down.

Rodiani (2015) menjelaskan dalam artikelnya bahwa menurut Marder (2001), Sindroma Down (Down Syndrome)adalah suatu kondisi keterbelakanganperkembangan fisik dan mental pada anakyang diakibatkan adanya abnormalitasperkembangan kromosom. Kelainan initerbentuk akibat kegagalan sepasangkromosom untuk saling memisahkan diri saatterjadi pembelahan. Kelainan genetik yangterjadi pada kromosom 21 pada lengan q22 gen SLC5A3 yang dapat dikenal dengan melihat manifestasi klinis yang khas.Karakteristik orang dengan Sindrom Down antara lain: memiliki kekhasan yang hampir serupa pada wajah, mata, rambut, badan, dan ciri fisik lainnya; memiliki tingkat ketidakmampuan belajar dan hambatan pertumbuhan (berbeda satu dengan yang lain); dampak keterbelakangan mental seperti perilaku impulsif, kesulitan dalam mengambil keputusan hingga kemampuan atensi minim juga dapat terjadi; dan anak-anak dengan sindrom Down masih bisa tumbuh normal secara kognitif dan sosial walau proses ini membutuhkan waktu lebih lama daripada anak biasanya(www.alodokter.com., 2016).

\section{Nilai Etis Filosofis Deteksi Dini Janin dengan Teknologi dan dampaknya}

Mengapa orang ingin tahu lebih awal kondisi calon bayi yang masih ada dalam kandungan?Mengapa kita tidak menunggu saja bayi tersebut lahir kemudian mengurusnya sesuai dengan kondisi kelahirannya?Apakah teknologi yang digunakan dalam kedokteran untuk mengetahui kondisi janin benar-benar bermanfaat? Apakah jika kita mengetahui kondisi janin akan berpikir untuk melakukan yang terbaik atau malah sebaliknya berpikir untuk menggugurkan saja ketika bayi dalam kandungan tersebut memiliki kelainan yang tidak diharapkan dan tidak bisa disembuhkan? Apakah teknologi USG cukup saja untuk mengetahui jenis kelamin dan ukuran badan janin dalam perkembangannya?Pertanyaan-pertanyaan tersebut menjadi terlontar ketika perkembangan teknologi ternyata dapat membantu para praktisi kesehatan menjelaskan kondisi calon bayi dalam kandungan kepada orang tuanya.

Teknologi yang dikembangkan dalam kedokteran atau kesehatan adalah teknologi yang bertujuan untuk meningkatkan kesejahteraan manusia. Menurut Firman (2018), konsiderasi moral seyogyanya menjadi satu rambu-rambu penting yang perlu diperhatikan demi mempertahankan eksistensi manusia dan nilai-nilai kemanusiaan. Dengan demikian dalam konteks "sains untuk kesejahteraan umat manusia", maka kegiatan sains seyogyanya tidak bebas nilai khususnya dalam menentukan arah riset dan aplikasi sains.Teknologi adalah aplikasi sains dan teknologi dalam bidang kesehatan adalah upaya mempertahankan eksistensi manusia.Maka teknologi yang 
dikembangkan dan diterapkan dalam bidang kesehatan seharusnya juga memiliki batasan nilai dan mempertimbangkan dampak yang mungkin terjadi berupa pelanggaran nilai-nilai kemanusiaan.

"Apabila ada sepasang suami istri, yang sedang menunggu kelahiran anaknya dan mereka adalah orang yang paham fungsi dari teknologi USG dan metode lainnya untuk mendeteksi kelainan pada janin (karena rajin mencari informasi di internet), kemudian memeriksa kehamilan sang istri ke dokter kandungan dengan alat yang canggih karena mereka mampu membayarnya. Hasil USG menunjukkan indikasi adanya kelainan Sindroma Down, kemudian dokter spesialis kandungan tersebut menyarankan untuk mengikuti prosedur tes agar lebih yakin. Sepasang suami istri tersebut mengikuti anjuran sang dokter kandungan. Hasil tes laboratorium yang sudah mumpuni menguatkan indikasi dari hasil USG sebelumnya."Apa yang kira-kira terjadi kepada sepasang suami istri tersebut? Akankah dengan mudah mereka menerima hasil tes tersebut? Apakah mereka akan tetap merasa senang seperti awal mereka tahu bahwa sang istri positif hamil? Atau mungkinkah mereka akan berpikir untuk menggugurkan kandungan tersebut karena merasa tidak siap menerima kenyataan harus memiliki anak dengan Sindrom Down?

Idealnya pemeriksaan kesehatan janin dalam kandungan adalah proses untuk mempersiapkan kemungkinan-kemungkinan yang perlu dilakukan pada saat kelahiran dan perkembangan bayi sampai menjadi dewasa. Jika hasil pemeriksaan dini atau tes diagnosis tidak menunjukkan abnormalitas, maka semua akan berjalan normal saja. Jika ada suatu abnormalitas yang biasa terjadi, misalnya tali pusar melilit ke bagian badan janin, maka dokter kandungan akan menyiapkan prosedur seperti operasi jika diperlukan. Jika ditemui kelainan yang masih mungkin dapat diperbaiki setelah lahir, misalnya kelainan jantung, maka dokter biasa menyiapkan prosedur operasi dan penanganan lanjutannya dengan berbagai teknologi yang ada sehingga bayi yang lahir dapat tetap tertolong.Jika yang ditemui adalah kondisi yang kelainan permanen seperti kecacatan bawaan, maka tanggung jawab para dokter adalah menyiapkan kondisi kedua orang tua untuk menerima bayinya nanti.Tetapi apakah semua orang tua siap secara mental mengetahui kondisi calon bayi mereka jika yang terjadi adalah adanya kecacatan fisik atau bahkan mental kognisi dari bayi ketika lahir nanti?

Konteks ilustrasi di atas dapat terjadi di negara mana saja dengan budaya dan aturan hukum yang berbeda-beda. Jika kejadian tersebut terjadi di Indonesia, walaupun mungkin jarang orang tua yang paham fungsi deteksi kelainan oleh USG, maka kemungkinan-kemungkinan yang terjadi akan sangat terkait dengan latar belakang sepasang suami istri tersebut. Pengguguran kandungan di Indonesia adalah perbuatan yang ilegal, tidak akan dokter atau tenaga medis lainnya yang akan menyarankan atau mau melakukan pengguguruan kandungan jika mereka taat dengan sumpah profesi dan aturan hukum yang berlaku di Indonesia. Apakah jika kemudian ternyata tetap terjadi pengguguran kandungan, yang pasti adalah perbuatan ilegal, maka teknologi kedokteran yang mendeteksi kondisi calon bayi tersebut ikut dipermasalahkan?Tanggung jawab etis dari suatu teknologi atau hasil ilmu pengetahuan menjadi abu-abu dalam hal ini.Aksiologi dalam filsafat yang mencakup nilai dan penilaian dari suatu objek salah satunya berhubungan dengan etika yang membicarakan perilaku manusia (Wiramihardja, 2009).Apakah dalam hal ini kesalahan juga berada di pihak praktisi medis yang menerangkan dengan jelas bahwa calon bayi tersebut mengidap Sindrom Down?Atau tetap hanya perilaku kedua orang tua calon bayi tersebut saja yang melanggar etika? Orang tua tertentu dengan latar belakang tertentu mungkin akan siap dengan segala kemungkinan, tetapi orang tua lain bisa menajdi tidak siap dan memilih jalur ilegal dengan alasan ketidaksiapan tersebut.

Bagaimana jika konteksnya bukan di negara kita? Bagaimana konteksnya bila pengguguran kandungan adalah proses yang legal dengan alasan medis? Pembenaran bahwa bayi yang lahir nantinya akan menjadi bayi yang tidak sehat secara kognisi? Budaya dan hukum positif juga akan menentukan kadar etis atau tidak etisnya fenomena tersebut. Data World Health Organization (WHO) menunjukkan salah satu alasan terjadinya aborsi atau pengguguran kandungan adalah resiko terhadap kesehatan fisik dan mental (dalam www.ncbi.nlm.nih.gov, 2017).Data tersebut juga menunjukkan bahwa aborsi yang dulunya berbahaya bagi ibu yang mengandung, saat ini sudah lebih aman jika dilakukan dengan prosedur medis yang benar. Artinya ada dokter-dokter atau tenaga medis lainnya yang melakukan aborsi sesuai prosedur, tetapi tentunya hal ini hanya terjadi di negara-negara yang memiliki hukum melegalkan aborsi pada kondisi tertentu, misalnya usia kehamilan tertentu atau alasan lain yang dibolehkan.

Dewasa ini ilmu bahkan sudah berada diambang kemajuan mempengaruhi reproduksi dan penciptaan manusia, yaitu dengan adanya revolusi genetika (Suriasumantri, 2005).Kloning manusia memang belum dilakukan saat ini, tetapi keberhasilan kloning terhadap hewan adalah langkah revolusioner suatu seleksi atas reproduksi mahluk hidup. Kaitan dengan teknologi yang 
mampu mendeteksi kelainan janin adalah bahwa manusia mungkin akan terpikir untuk menyeleksi siapa yang berhak lahir dan hidup di Bumi ini ketika dirasa populasi manusia sudah terlalu banyak. Pikiran ini memang terlalu naif, tetapi bagi orang tua yang tidak siap secara mental atau mungkin secara ekonomi, mengasuh dan membesarkan anak dengan keterbatasan seperti Sindrom Down, akan menjadi pembenaran untuk mencegah kelahiran janin tersebut. Apakah pikiran ini terlalu berlebihan?

Artikel pada kotak di bawah ini mengenai data-data yang dimiliki WHO terkait aborsi di beberapa negara maju yang telah melegalkan aborsi dengan alasan tertentu.

\begin{tabular}{|c|}
\hline \\
In the United States each year, more than \\
6,000 babies with Down syndrome are \\
born, according to the National Down \\
Syndrome Society. However, almost none \\
are born in Iceland. That's because nearly \\
100 percent of women in Iceland who \\
receive a positive test for Down syndrome \\
choose to terminate the \\
pregnancy. Iceland isn't alone in having \\
high termination rates. In Denmark, 98 \\
percent of pregnancies with a Down \\
syndrome diagnosis are terminated.In \\
France, it's 77 percent, and in the United \\
States it's 67 percent. \\
(www.healthline.com., 2017). \\
\end{tabular}

Jika data-data pada kotak artikel di atas adalah data-data yang dapat dipertanggungjawabkan, maka sudah terlihat bahwa terjadi proses bebas nilai terhadap informasi yang didapatkan dari penggunaan teknologi dalam bidang kesehatan, yaitu pencegahan kelahiran dari janin yang dideteksi memiliki kelainan. Aborsi yang dilakukan sudah pasti adalah dampak dari aplikasi teknologi, khususnya deteksi dini pada kondisi janin, apapun metodenya.Lalu bagaimana tanggung jawab moral etis dari para ilmuwan yang membuat peralatan tersebut?Bagaimana tanggung jawab para praktisi kesehatan yang membuat itu terjadi?Bolehkan nyawa manusia, walaupun masih dalam kandungan, dicegah kelahirannya?

Aturan hukum di sebagian besar negara maju dan berkembang telah memasukan aborsi sebagai bagiannya.Penerapannya tentu sesuai dengan kapasitas para penegak hukum di negaranegara tersebut.Beberapa negara memang melegalkan aborsi, tetapi dengan kriteria atau alasan yang sangat terbatas.Alasan aborsi menjadi legal terutama adalah kesehatan dan keselamatan ibu yang mengandung janin, tetapi ada sedikit negara yang melegalkan aborsi sesuai permintaan (www.ncbi.nlm.nih.gov., 2017). Tidak dijelaskan permintaan seperti apa yang membuat aborsi menjadi legal, karena aborsi sesuai permintaan itu terpisah dari alasan lain yang lebih jelas seperti kesehatan mental ibu, faktor ekonomi, dan kelainan janin. Apakah aborsi yang terjadi seperti datadata pada kotak di atas berdasarkan legalitas kelainan janin tersebut atau cukup berdasarkan permintaan tidak ada penjelasan yang bisa menjawabnya.Kondisi tersebut tidak terlihat menggambarkan kondisi di Indonesia tentunya.Aborsi di Indonesia juga sudah masuk ke ranah hukum pidana, tetapi data aborsi karena kelainan janin sepertinya belum ada. Aborsi di Indonesia, jika kita mencermati berita di media massa, sebagian didominasi karena masalah moral orang tuanya bukan karena kelainan pada calon bayinya.

Ilmuwan mempunyai kewajiban sosial untuk menyampaikan kepada masyarakat banyak dalam bahasa yang dapat mereka cerna (Suriasumantri, 2005).Pendapat tersebut dapat dikembangkan menjadi sebuah tanggung jawab sosial dari orang-orang yang kompeten.Permasalahan teknologi, yang awalnya membantu para dokter mengetahui perkembangan janin tapi kemudian dijadikan informasi untuk melakukan aborsi, adalah permasalahan yang harus dapat dijelaskan oleh orang-orang yang kompeten, dalam hal ini para ahli kesehatan, kepada masyarakat awam khususnya para orang tua calon bayi.Jika hukum positif di Indonesia masih belum melegalkan aborsi serta budaya bangsa ini yang mentabukan pengguguran kandungan, maka perlu diperhatikan ekses dari penerapan sains tersebut.Perlu 
adanya kesepahaman dari para dokter, sejauh mana penggunaan USG dalam mendeteksi kelainan pada bayi.Bukan penggunaannya yang dibatasi sebenarnya, tetapi para spesialis kandungan tersebut perlu juga memahami psikologis calon ayah/ibu dari janin dalam kandungan.Sebuah tanggung jawab moral untuk mencegah penyimpangan dari tujuan penciptaan teknologi.

Teknologi USG dan mentode pemeriksaan kehamilan lainnya mungkin tidak bernilai sangat luar biasa dibandingkan revolusi genetika (kloning), tetapi intensitas penerapannya tentu jauh lebih tinggi disbanding kloning yang lebih bersifat eksperimen (saat ini). Sebagian besar ibu hamil akan mengunjungi bidan atau dokter kandungan ketika memeriksakan kehamilannya. Alat USG itu sendiri telah mencapai daerah-daerah yang bahkan jauh dari perkotaan, karena telah ada pula Pusat Kesehatan Masyarakat (Puskesmas) yang memiliki perangkat tersebut.Informasi mengenai kelainan pada manusia tentunya juga sudah dapat diakses oleh masyarakat umum, bahkan dipelajari di sekolah.Arus teknologi dan informasi tidak dapat dibendung di masa sekarang ini, maka pendidikan menjadi salah satu faktor yang dapat membuat teknologi dan infromasi tersebut dimanfaatkan dan berdampak sesuai tujuannya.IImuwan dan praktisi-praktisi ilmu yang kompeten perlu menjembatani sehingga pendidikan dapat membuat manfaat sains tetap dalam koridor etis dan batasan nilai yang proporsional.

\section{Simpulan}

Aplikasi sains berupa teknologi dalam bidang kesehatan telah dimanfaatkan untuk membantu para dokter kandungan mendeteksi kesehatan atau kelainan pada janin dalam kandungan.Pemeriksaan dini tersebut bertujuan untuk menyiapkan prosedur kelahiran dan penanganan tindak lanjut yang tepat kepada bayi yang lahir.Tujuan yang baik dari pengembangan teknologi tersebut ternyata dapat menyimpang atau terjadi ekses negatif ketika penggunanya tidak mampu menahan diri untuk tetap berada pada nilai-nilai yang baik dari budaya, hukum, dan kemanusiaan.

Kelainan pada janin yang akan terbawa sampai kelahiran dan tumbuh kembangnya dapat menjadi alasan untuk melanggar nilai-nilai yang baik. Aborsi yang pada kenyataannya adalah mematikan calon bayi yang akan lahir adalah langkah yang mungkin diambil oleh orang tua yang tidak siap menerima kenyataan keturunannya memiliki keterbatasan dan memerlukan perhatian khusus.Pelanggaran nilai-nilai kemanusiaan tentunya adalah batasan yang tetap harus dimiliki dalam penerapan teknologi, langsung ataupun tidak langsung.Aborsi tentunya bukan dampak yang diharapkan dari deteksi dini kesehatan janin dalam kandungan, tetapi masalahnya aborsi karena janin terindikasi Sindrom Down diakibatkan penggunaan teknologi atau aplikasi sains tersebut.Dampak itulah yang perlu dipikirkan oleh para ilmuwan dan praktisi kesehatan yang kompeten, sehingga tidak terjadi lagi aborsi karena alasan indikasi kelainan janin, tetapi bagaimana agar bayi yang lahir tetap dapat tumbuh dan berkembang sesuai yang diharapkan. Mungkin masih diperlukan sains yang lebih maju lagi untuk memperbaiki kelainan tersebut sehingga tidak menjadi aspek yang ditakuti oleh orang tua yang akan memiliki keturunan.

\section{Daftar Pustaka}

Abdulhak, I. (2008). Filsafat ilmu pendidikan. Bandung:Remaja Rosdakarya.

Akinpelu, J.A..1988. An Introduction to Philosophy of Education.London and Basingstoke: Macmillan Publishers Ltd.

Al-Syaibany, Omar Mohammad Al-Toumy. 1979. Falsafah Pendidikan Islam.Jakarta: Bulan Bintang.

Barnadib, Imam.1996. Filsafat Pendidikan - Sistem dan Metode. Yogyakarta:Andi Offset.

Firman, H. (2018). Filsafat Sains. Program Studi Pendidikan IPA. Sekolah Pasca Sarjana UPI.

Gazalba, Sidi. 1973. Sistematika Filsafat. Jakarta: Bulan Bintang.

Jalaludin \& Abdullah Idi.1997. Filsafat Pendidikan. Jakarta: Gaya Media Pratama.

Kattsoff, Louis O. 1987. Pengantar Filsafat. Yogyakarta: Tiara Wacana.Penerjemah: Soejono Soemargono. 
Maksum,Ali.2009. "Pengantar Filsafat: Dari Masa Klasik Hingga Postmodernisme”. Maguwoharjo, Depok, Sleman, Jogjakarta : Penerbit Ar-Ruzz Media,

Salam, B. (1997). Logika materil filsafat ilmu pengetahuan. Jakarta:Rineka Cipta.

SanprayogiMaria. 2017. Aksiologi Filsafat IImu dalam Pengembangan Keilmuan. Jurnal Study Kependidikan dan Keislaman Universitas Muhammadiyah Ponorogo. Vol. 4, No. 1.

Santosa, Nyong Eka Teguh Iman (2012) Filsafat Pendidikan Muhammadiyah Akhir Zaman. Universitas Muhammadiyah Sidoarjo. Retrieved from http://eprints.umsida.ac.id/201/1/filsafat\%20pendidikan\%20akhir\%20zaman-2012.pdf

Santosa, Nyong Eka Teguh Iman. Epistemologi Partisan Pendidikan Liberal. Adabiyah: Jurnal Pendidikan Islam, Vol. 1, No. 1, September 2015. DOI:http://dx.doi.org/10.21070/ja.v1i1.160. Retrieved from http://ojs.umsida.ac.id/index.php/ajpi/article/view/160.

Suriasumantri, J.S. (2005). Filsafat IImu Sebuah Pengantar Populer. Jakarta: Pustaka Sinar Harapan.

Wiramihardja, S. A. 2009. Pengantar Filsafat: Sistematika dan Sejarah Filsafat, Logika dan Filsafat IImu (Epistemologi), Metafisika dan Filsafat Manusia, Aksiologi. Bandung: PT. Refika Aditama.

Wihadi, Admojo et.al. Kamus Bahasa Indonesia. Jakarta: Balai Pustaka. 